\title{
Power Devolution and Electricity Transmission in Nigeria: A Study in Resources Mobilization for Economic Development
}

\author{
Charles A. Obiora PhD \\ Department of Political Science \\ Chukwuemeka Odumegwu Ojukwu University, Igbariam \\ Amobi P. Chiamogu \\ Department of Public Administration \\ Federal Polytechnic, Oko \\ Uchechukwu P. Chiamogu \\ Department of Public Administration \\ Federal Polytechnic, Oko
}

\begin{abstract}
The 1979 and 1999 constitutions of Nigeria created anti-development frameworks that unhealthily endowed the federal government with excessive powers in direct contravention of the most basic tenets of federalism. One of the items that has remained subtly contrived in the exclusive list is power generation. The 2005 Electric Power Sector Reform Act through Sections 8, 65 and 66 established and licensed Transmission Company of Nigeria (TCN) to take charge of transmission and system operation of high voltage network of the Nigerian electricity supply industry. Thus, the Nigerian energy policy structure continues to be top-down involving huge investments in large electricity mega plants, generating electricity into mega grids for mega distribution. Based mainly on secondary sources of data, this paper is a descriptive and analytical clarification of issues on power sharing as key impediment to poor electricity generation, transmission and distribution in Nigeria. The study examines the implications of power behemoth federal government that stifles autonomy of federating units in Nigeria. It observes that the exclusive right to electricity transmission by the federal government negates sustainable electric power supply in Nigeria. It therefore recommended devolution of powers and streamlining of Second Schedule of 1999 Constitution to reflect a true federal system
\end{abstract}

Keywords: Power Devolution, Federalism, National Transmission Grid, Electricity Transmission, Electricity Generation, Resources Mobilization, Electricity Distribution, Nigerian Energy Policy, On-Grid Electricity Generation and Economic Development

\section{INTRODUCTION}

Federalism is one of the most important constitutional concepts and designs which enable legitimacy of political power with regard to a fragmented society (Fleiner, 2006). Ostensibly however, one of the major reasons for the political and economic problems confronting Nigeria is that too much power is concentrated at the centre as represented by the exclusive legislative list (Osunbor, 2017). This list houses about 68 items that make the power sharing structure of the Nigerian federalism to be lopsided and skewed to central government being the trendsetter. The federal government obviously assumed too much powers and functions that significantly debilitate the component units thereby making the latter to be dependent upon the largesse from the former to survive. Ordinarily, devolution of powers is intended to meet the agitations for true federalism, restructuring, marginalization and crave for accelerated 
regional growth and development. These concepts and perspectives on the argument of a better united Nigeria tends to give hopes on the capacity of States to function effectively as federating units while providing sustainable platform for greater resources mobilization and utilization for unity in diversified seemingly independent entities in the state of Nigeria.

On the other hand, the issue of participation by the different federating units in decision making processes is the most sensitive issue of legitimacy of the federation. Indeed through their participation the federal government is required to find solutions to accommodate the federating units and establish justice within the entire community. Reaffirming the lopsided structure of centralization in a federal system, the power policy structure provides for all generated energies in the country to be pumped into the national grid for unified and coordinated transmission and distribution. Yes, mines and minerals are contained in the contested exclusive list which grants only the federal government authority to legislate upon power generation, transmission and distribution in Nigeria, the states are stranded as par the challenges of power supply. In spite of natural endowments that granted these component units comparative advantages, the power sharing formular invariably inhibits resources mobilization, utilization and possible competition to engender economic growth and development.

Electric power generation in Nigeria however dates back to 1886 when two (2) generating sets were installed to serve the then Colony of Lagos. By an Act of Parliament in 1951, the Electricity Corporation of Nigeria (ECN) was established, and in 1962, the Niger Dams Authority (NDA) was also established for the development of hydroelectric power. A merger of the two organizations in 1972 resulted in the formation of the National Electric Power Authority (NEPA) which was saddled with the responsibility of generating, transmitting and distributing electricity for the whole country (NERC, n.d). In 2005, as a result of the power sector reform process, NEPA was unbundled and renamed Power Holding Company of Nigeria (PHCN). The Electric Power Sector Reform (EPSR) Act enabled private companies to participate in electricity generation, and distribution. Subsequently, the government further unbundled PHCN into eleven Electricity Distribution Companies (DisCos), six Generating Companies (GenCos), and a Transmission Company (TCN). The Act also created the Nigerian Electricity Regulatory Commission (NERC) as an independent regulator for the sector.

Obviously, one of the challenges that bedevil socio-economic development in Nigeria is electricity supply. In the 21st century amidst different options for energy generation, Nigerians have been conditioned into thinking that power failure is part of national way of life (Eghagha, 2017). The Nigerian population is estimated to be above one hundred and eighty three million and about $55 \%$ of the population have no access to grid-connected electricity (Nigeria Power Baseline Report -nesistats.org). Access to electricity in the rural areas is about $35 \%$ and about $55 \%$ in the urban areas (Financial Nigeria, 2017). During the administration of President Goodluck Ebele Jonathan, Governors Babatunde Raji Fashola of Lagos and Chibuike Amaechi of Rivers generated chunks of electricity from their state independent power plants but were not granted freedom to transmit and distribute such to their people. At a point in Lagos, the state had excess electricity which it generated for its public infrastructure but could not distribute the surplus to private residences as a way of dealing with the shortages from the national grid. To the extent of the foregoing, this paper attempts a critical examination of the dynamics, nature and intransigent provisions of Sections 8, 65 and 66 of the 2005 Electric Power Sector Reform Act that did not only establish but mandated the Transmission Company of Nigeria (TCN) the sole right to determine and regulate transmission of high voltage that empowers national grid system which has occasioned a centralized power distribution. It also questions 
the rationale for the pumping in of all generated electric power into the national grid that is not only redundant but does not have the requisite capacity to deliver more than $7000 \mathrm{MW}$ whereas the energy needs of the country is place above that limit. Since the 2005 Act granted liberalization of energy generation and distribution, this study wonders why the government still retains those sections for a government agency to be in-charge of transmission that has continued to retard economic growth.

\section{CONTEXTUAL AND CONCEPTUAL CLARIFICATIONS}

A number of concepts that form the bases of this study along those that are significantly intervening in the discourse are redefined in terms that would facilitate better comprehension. They include: power devolution, federalism, national transmission grid and, resources mobilization.

\section{What is Power Devolution}

The Exclusive Legislative List contains too much powers in the Nigerian federal system of government such that the federal government has assumed the position of leader and repository of powers and functions thereby becoming overbearing and so large that it is geometrically rendering the component units of the Nigerian federation irrelevant and stagnated. Power devolution thus is a concept that is intended to meet the agitations for "true federalism", fiscal federalism, restructuring, etc (Osunbor, 2017). According to Odigbo (2013, p. 37-43) devolution deals with power relations among levels of government that distinguishes institutions in terms of structure, power they possess, functions they perform and how they formally relate to each other. Amongst several other positions, Ferguson and Chandrasekharan (n.d) see devolution as the transfer of governance responsibility for specified functions to subnational levels, either publicly or privately owned, that are largely outside the direct control of the central government. Hence, power devolution is designed to create a political environment in which power to access political, economical, natural and social resources is distributed between the central and other levels of government. It implies appropriate sharing of powers in a manner that grant the component units relative independence and latitude for cooperation with the federal government. It enhances the principles of federalism and good governance by allowing the regional or state governments opportunities of identifying and utilizing their material and human resources to foster economic growth and development.

\section{A Re-definition of the Concept of Federalism}

The independence constitution of 1960 was anchored on the principles of federalism owing to the unanimous agreement between Nigerian founding fathers and British colonial authorities that the model was suitable for the socio-cultural and historical diversities in the emergent Nigerian state (Osagie, 2017). Federalism nevertheless is one of the most important constitutional concepts and designs which enable legitimacy of political power to integrate and enhance the fragmentation of the society (Fleiner, 2006). It according to Tella, Doho and Bapeto (2014, p. 51-66) is a political structure that allows states to unite under a central government to maintain a measure of independence and interdependence. However, the Nigerian federal system did not come as a result of the coming together of separate states but was the subdivision of the country into regions (Mackintosh, 1962). In any case, federalism just like the notion from Wheare (1963) describes a pattern of division of powers between one general and several regional governments, each of which, in its own sphere, is co-ordinate with the others; each government must act directly on the people; each must be limited to its own sphere of action; and each must within that sphere, be independent of the others. Thus, federalism explains the method of power sharing in plural societies between the national and component units. In Nigeria, political powers are shared between the federal and state governments in a manner that paved the way for unimaginable volume of powers to be 
contained in the exclusive legislative list against the duo of concurrent and residual legislative lists. The latter lists comprise areas of authority where the federating units can legislate upon.

\section{A Description of National Transmission Grid}

Electricity is generated at power plants and moves through a complex system, sometimes called the grid, of electricity substations, transformers, and power lines that connect electricity producers and consumers (U.S. Energy Information Administration, 2017). The transmission grid is an integral part of the electricity value chain whose operation network is vested in the TCN (Omonfoman, 2016). On-grid generation refers to a system of power generation evacuated through the national grid to off-takers which may be the bulk trader, (Nigerian Bulk Electricity Trading Company Plc.) who through vesting contracts supplies the power to distribution companies; or directly to eligible customers, as may be declared by the Minister of Power (Financial Nigeria, 2017). TCN is the only successor company in the electricity value chain still in government control and it has a management contract with Manitoba Hydro International Limited, a Canadian utility firm. Its operations cover the whole country but it is administratively subdivided into 8 transmission regions that contain various work centers with a national control centre (NCC) in Osogbo and 3 regional control centers. TCN's core mandate broadly covers the operation and management of high voltage $(330 / 132 \mathrm{kV})$ transmission system assets, generation dispatch functions (system operations) and provision of open access transmission services on regulated tariff. The TCN, through the market operator, is also responsible for managing the electricity market settlement system based on a set of market rules.

The TCN is supposedly a balancing authority, whose primary job is to ensure that electricity supply constantly matches power demand. As a balancing authority, it also ensures that electricity demand and supply are finely balanced to maintain safe and reliable operation of the power system. In Nigeria, all generated electric powers are pumped into series of grids that are interconnected for reliability and commercial purposes, forming larger, more dependable networks for purposes of enhanced coordination and planning of electricity supply. This interconnection which delivers converted high voltage electricity to industrial and domestic consumers describes the national grid. This grid is centralized and managed by the TCN which implies that in spite of the deregulation of generation and distribution that transmission is still being handled by the government. Hence, GenCos and DisCos cannot connect their customers directly. They must pump their energy into the national grid that has been confirmed to be archai and grossly deficient in coverage of the country.

\section{What then is Resources Mobilization}

According to Enogholase (2017), the 36 states of Nigeria have become mere appendages to the distant federal government in Abuja whose major responsibility is to preside over revenues generated at the state levels only to dole out crumbs back to the states. That is an aberration. In a truly federal system, the component units harness their socio-economic and natural potentials and remit what is due to the federal government from sales of commodities within its borders for effective and concentrated form of widespread economic stimulation. Invariably, power devolution would grant regional and state governments opportunities of direct governance of their resources in their borders. The Niger Delta states and some Eastern states have abundant gas reserves and resources to build gas-driven power plants in their regions and offer their people uninterrupted power supply. The only obstacle also hindering this possibility is the Federal Government and the 1999 Constitution that debar these areas from generating and distributing electricity without first connecting it to the national grid. Niger State is a host to three dams with a combined capacity of $1,900 \mathrm{MW}$ of potential electricity production through hydro plants, yet the state is in darkness (Osborg, 2016). 
Zamfara State has abundant wind to generate electricity for some parts of its territory, but according to the 1999 Constitution, no state has the power to exclusively distribute electricity it generates without sending such to the national grid. Sokoto, Kano, Borno, Kogi, Enugu and all other states in Nigeria have their natural comparative advantages in generating and distributing electricity to their people, however federal laws have remained obstacles to this. Which is the main reason why Nigeria does not have enough electricity, as these states are obstructed from producing and distributing electricity in a competitive manner.

\section{THEORETICAL EXPOSITION - DEMOCRATIC LOCAL GOVERNANCE APPROACH}

This study is basically anchored on evolving notions and perspectives on democratic local governance approach. Democratic local governance is a framework which is grossly rooted in the concepts of power decentralization that has assumed several forms. In that regards, the analysis of the issues canvassed in the study problematique are based upon the perspectives of this approach which eventually formed the lens for understanding rationale for power transfer from the central government to the component units in a federation.

The application of decentralization in its varied forms in plural societies has played several important roles in fostering accountable and responsible governance (Hidayat, 2017). Cheema and Rondinelli (2007) outlined three forms of decentralization, that act as a way for transferring authority, responsibility, and resources to include deconcentration, delegation, or devolution of power from the center to other levels of government and administration. Decentralization according to them is more likely to produce a diversity of policy responses. Hence, decentralization of powers in any of its forms offer options for local development according to the needs of the people in their areas. Also, democratic local governance framework creates or strengthens channels and mechanisms for public participation in the decision-making process as well as guaranteeing observance of the rule of law for increased transparency and accountability in public procedures (Kaufmann, Kraay, \& Mastruzzi, 2004).

Furthermore, power devolution focuses on organizations and procedures for increasing citizen participation in governance of both human and material resources. This invariably implies that by devolving right to legislate on power generation and transmission to the component units, state governments and the general public would have opportunities of robust investment in the power sector that could conduce to perfect competition and give rise to both direct and indirect socio-economic implications beneficial to production of goods and services in Nigeria. Moreover, political power devolution promotes the principles of democratization in the sense of assisting the development of responsive policies and services that provide more meaningful opportunities for greater citizens' participation in the political process (Cheema \& Rondinelli, 2007). In short, it will promote the values of "bringing government closer to the people." From this framework, we can understand that decentralization would provide platforms for greater accessibility, accountability, and responsibility to the local jurisdictions of political and administrative authority.

In that order, Rondinelli and Cheema (2003) argue that decentralization processes include patterns of reform and restructuring of vertical and horizontal structures, policies and institutions of the government. Several theorists endorse decentralization as an important tool for improving the quality of government. Some of them include (Ostrom, Schoreder, and Wayne, 1993; Tiebout, 1956; Inman and Rubinfield, 1997). Those theorists believe that decentralized units of government have a greater incentive to be more efficient, as well as providing competition among levels and institutions of government. 
Analyzing the foregoing discourse on devolution, Burki, Perry, and Dillinger (1999) propose that the trends toward decentralization constitute outcomes of the declining credibility of the centralized state and form part of a broader trend toward democracy. In that vein, Falleti (2010) argues that decentralization is transformative in its ability to transfer the role of central government under the principle of subsidiarity. Therefore, it could be surmised that devolution of political power offers the local sphere, requisite wisdom to fulfill unit interests. Thus, the decentralized system will attach more importance to the notion of supporting appropriate harnessing of the potentials of localities in a creative process than in a centralized government context. Highly centralized governments tends to be unresponsive, inefficient, as well as detaching localities from their local wisdom. This paper therefore argues that political power devolution endorses the value of diversity of government units in autonomy and is more likely to produce a diversity of policy responses that facilitate mobilization, augmentation and utilization of natural and human resources to citizens' needs such as generation and effective transmission of electricity.

\section{Why devolving the National Transmission Grid}

According to Metering and Smart Energy Information (2017), Nigeria has 13,400MW of installed power generation capacity of which $8,000 \mathrm{MW}$ is mechanically available. However, less than 4,000 MW has been dispatched on average over the last 2 years due to constraints in gas supply, electricity transmission and distribution. Most of the power received by Nigerian electricity consumers is on-grid power supplied by the Distribution Companies (DISCOs). Ongrid power generation has over the years had its constraints. The existing transmission system is only capable of delivering about $5,300 \mathrm{MW}$ against the total installed capacity of power to Discos trading points. This is as a result of Nigeria's current weak transmission infrastructure that is majorly radial, which means that it's a single path of transmission with a power source at one end. This indicates that any fault in the path could potentially lead to a collapse of the transmission network.

The issue with transmission has been estimated to reduce the power generation capacity by a total of about 263MW. The transmission infrastructure in its current state, without an upgrade and improved technology, is unable to accommodate the estimated increase in generation by 2020. It has been estimated that developing economies would need about 1,000MW per million people to meet their electricity demand. Invariably, Nigeria would require more than $160,000 \mathrm{MW}$ to achieve the desired electricity generation capacity. At 45\%, Nigeria's electrification rate is low - much lower than that of Ghana (72\%) and South Africa (85\%). Furthermore, unreliable power supply forces both households and industry to rely on privately owned generators for much of their power. Widespread inefficiency means that only 3,879MW of this capacity is operational with $3,600 \mathrm{MW}$ transmitted and 3,100MW distributed (Nigeria Power Baseline Report, 2015).

What is more, since the installed capacity of the national grid cannot accommodate the electricity demand of Nigeria based on poor coverage and outdated infrastructure, does it still provide the required functions? If the amount of power generated by the IPPs in Lagos can provide Lagos and its environs constant supply, would it not be better to take the Lagos IPPs out of the archaic national grid? Would it not also make sense for the IPPs in the Niger Delta or Sokoto or Kano or Sapele to supply power to their immediate environment? There is urgent need for Nigeria to dispense with the national grid and allow the generated power to be supplied directly to consumers? We acknowledge the inherent risks but in the meantime let there be electricity supply. 


\section{ECONOMIC IMPLICATIONS OF DISINTEGRATING THE NATIONAL GRID}

It is rather unfortunate that there is no part of the Nigeria that enjoys regular power supply because all generated electric power must be lumped together unto a weak link - the national grid. This divest investors from moving into the deregulated power sector and retards economic development. Poor supply of electricity paves way for massive reliance upon privately owned generators for both industrial and household use. These generators are more than twice as expensive (NGN 62 - 94/kWh) than grid-based power (end user tariff of NGN 26 $38 / \mathrm{kWh}$ ) thereby making the cost of doing business to be high and dissuading production.

At disintegration of the national grid and development of off-grid captured in a manner that regional, states and local governments can participate in power planting - generation, transmission and distribution; the extractive capabilities of the component units of the Nigerian federation would be geared up. States and other units of the federation would undertake policies that would facilitate exploration and exploitation of their natural and human resources. State governments would exploit their comparative advantages in the development of their areas. For instance, there is abundances of natural gas deposit along the Anambra basin, Enugu has coal deposits,

Need for other fuel alternatives: Most of the power plants in Nigeria are gas fired thermal plants. Given the current constraints with gas, off-grid power plants are able to take advantage of diverse and hybrid fuel sources like renewables (solar, wind, biomass) and because the power is not generated on-grid, transmission constraints with renewables are eliminated. This would be particularly more useful in areas where there is limited gas supply, e.g. the northern part of Nigeria where solar, wind, and hydro sources are prevalent.

\section{RECOMMENDATIONS}

a) There is urgent need to dispense with the on-grid system of electricity transmission by devolving the national grid;

b) Sections 8, 65 and 66 of the EPSR Act, 2005 that established and licensed TCN to perform the functions of transmission and system operations of the High Voltage network of the Nigerian Electricity Supply Industry should be restructured and reformed to allow for off-grid power development and transmission. The off-grid approach should be decentralized among the federal, state and local governments to allow for faster implementation of off-grid projects through the actualization of longterm plans;

c) the unbundling of TCN into autonomous Transmission Services Provider (TSP) and System Operator (SO) should be fast tracked and concluded;

d) The National Renewable Energy and Energy Efficiency Policy for the Electricity Sector as approved by the Federal Government should be dusted and implemented;

e) There should be certainty in the regulations for off-grid solutions. There should also be clarity with respect to the criteria for generally licensing of off-grid projects in urban and industrial clusters;

f) A detailed review of the second schedule of the 1999 constitution to pave way for devolution of powers to the component units of the Nigerian federalism is thus recommended;

g) NERC should also create an avenue to enable easier licensing for off-grid licensees who have excess or stranded power, and wish to supply to the DISCOs;

h) That state governments should exploit and utilize their available natural resources towards effective power generation and transmission to stimulate economic growth and development; 
i) All public institutions starting with tertiary education institutions should engage in renewable energy development. They should exploit human wastes to generate electricity and power their institutions and their immediate environment.

\section{CONCLUSION}

The energy policy structure in Nigeria is top-down involving huge investments in large electricity mega plants, generating electricity into mega grids, for mega distribution through a centralized transmission network fondly referred to as the national grid. About 95 million Nigerians representing 55\% of the population have no access to electricity and those who are connected to the grid face extensive power interruptions. Systemic issues affect all phases of the power value chain (generation, gas supply, transmission and distribution) forcing Nigerians to rely on self-generation. Hence, it can be surmised that Nigeria can only achieve the desired increase in generation and transmission with a balanced blend of on-grid and off-grid power projects that would lead to an accelerated journey to full electrification. This would in turn result in a significant economic boost of the Nigerian economy, as power has been proven to be an enabler of other sectors of the economy.

\section{References}

Burki, S. J., Perry, G., \& Dillinger, W. R. (1999). Beyond the center: Decentralizing the state. Washington, DC: World Bank.

Cheema, G. S., \& Rondinelli, D. (2007). From government decentralization to decentralized governance. In G. S. Cheema \& D. Rondinelli (Eds.), Decentralizing governance: Emerging concepts and practices (pp. 1-20). Washington, DC: Brookings Institution Press

Eghagha, H. (2017, November 13). Federal ministry of power: Scrap the national grid! The Guardian. Retrieved from https://guardian.ng/opinion/federal-ministry-of-power-scrap-the-national-grid/ on May 19, 2018.

Enogholase, G. (2017, October 31). Devolution of power recipe for resource mobilization. Vanguard. Retrieved from https://www.vanguardngr.com/2017/10/devolution-power-recipe-resource-mobilisation-dep-vc/ on May 12,2018

Falleti, T. G. (2010). Decentralization and subnational politics in Latin America. Cambridge, UK: Cambridge University Press.

Ferguson, I., \& Chandrasekharan, C. (n.d). Paths and pitfalls of decentralization for Sustainable Forest Management: Experiences of the Asia-Pacific Region. A report commissioned by the International Tropical Timber Organization. Retrieved from

http://www.cifor.org/publications/pdf_files/events/documentations/interlaken/papers/Ferguson_Chandrasekh aran.pdf on May 22, 2018

Financial Nigeria (2017, June 10). Opportunities for off-grid solutions in the Nigerian power sector. Independent Energy Watch Initiative. Retrieved from http://iwin.org.ng/index.php/news/item/6625-opportunities-for-offgrid-solutions-in-the-nigerian-power-sector on May 17, 2018

Fleiner, T. (2006). Challenges of Devolution and Power Sharing Structures in Federations. Paper for the Conference on Comparative Constitutional Traditions in South Asia of the joint conference of SAIS and SOAS November 17th to November 192006 in London

Hidayat, R. (2017). Political Devolution: Lessons From a Decentralized Mode of Government in Indonesia. SAGE Open January-March 2017: 1-11. Retrieved from http://journals.sagepub.com/doi/pdf/10.1177/2158244016686812 on May 22, 2018

Inman, R. P., \& Rubinfeld, D. L. (1997). Rethinking federalism. The Journal of Economic Perspectives, 43-46.

Kaufmann, D., Kraay, A., \& Mastruzzi, M. (2004). Governance matters III: Governance indicators for 1996, 1998, 2000, and 2002. The World Bank Economic Review, 18, 253-287.

Mackintosh, J. P. (1962). Federalism in Nigeria. Sage Journal of Political Studies, 10(3).

Macionis, G. (2010). Sociology 7th Canadian Ed. Pearson Canada Inc., 
Metering and Smart Energy Information (2017, June 30). Nigeria's power sector recovery programme. Issue 3. Retrieved on May 18, 2018 from https://www.metering.com/magazine-article/power-sector-reformsnigeria/Nigeria Power Baseline Report, 2015

Nigerian Electricity Regulatory Commission (n.d). Power Generation in Nigeria. Retrieved from http://www.nercng.org/index.php/home/nesi/403-generation on May 21, 2018.

Odigbo, J. (2013). De-Constructing Decentralization and Devolution of Powers: Rethinking the Functionality of Local Government System in Nigeria. IOSR Journal Of Humanities And Social Science (IOSR-JHSS) Volume 15, Issue 1 (Sep. - Oct. 2013).

Osagie, E. (2017). Restructuring, devolution or disintegration: The choices before Nigeria in 2017. ElombahNews. Retrieved on May 21, 2018 from https://elombah.com/index.php/analysis/restructuring-devolution-ordisintegration-the-choices-before-nigeria-in-2017-by-prof-eghosa-osagie/

Osborg, T. (2016, August 20). True Federalism: States Must be Allowed to Generate and Distribute Electricity. Premium Times. Retrieved from https://opinion.premiumtimesng.com/2016/08/20/truefederalism-states-mustallowed-generate-distribute-electricity-tony-osborg/

Ostrom, E., Schroeder, L., \& Wynne, S. (1993). Analyzing in the performance of alternative institutional arrangements for sustaining rural infrastructures in developing countries. Journal of Public Administration Research and Theory, 3(1),11-45

Osunbor, O. A. (2017). Constitution amendment in Nigeria: Concepts and misconceptions. A presentation to students of the Faculty of Law, Ajayi Crowther University, Oyo, 31 January 2017.

Tella, C. M., Doho, A. W., \& Bapeto, A. (2014). The evolution, development and practice of federalism in Nigeria. Public Policy and Administration Review December 2014, Vol. 2, No. 4, pp. 51-66. Retrieved from http://pparnet.com/journals/ppar/Vol_2_No_4_December_2014/4.pdf on May 21, 2018

Tiebout, C. M. (1956). A pure theory of local expenditures. The Journal of Political Economy, 64, 416-424.

U.S. Energy Information Administration (2017, August 31). Electricity explained: How electricity is delivered to consumers. Energy Information Administration. Retrieved on May 21, 2018 from https://www.eia.gov/energyexplained/index.php?page=electricity_delivery

Wheare, K. C. (1963). Federal Government. 4th Edition. London: Oxford University Press 